\title{
"KARAKTERISTIK TEKANAN INFLASI DI INDONESIA: PENGARUH DINAMIS SISI PERMINTAAN-PENAWARAN DAN PROSPEK KE DEPAN"1
}

\author{
Solikin M. Juhro²
}

\begin{abstract}
This preliminary study is aimed to look into characteristics of inflation and sources of shocks triggering inflation pressures in Indonesia. A focus will be directed to find a better measurement about the role of supply and demand shocks. Based on parsimonious model estimation, it can be concluded that the contribution of supply shocks predominant demand shocks 'proportionally', implying that a prudent monetary policy is still feasible and can be implemented effectively along with the structural efforts to combat inflation in Indonesia. A further preliminary exercise shows that the prospect of inflation pressures in two year ahead will be statistically the same with the 2006 inflation pressures. However, cautious policy response should be taken in the second year as inflation pressures from supply side will be potentially greater.
\end{abstract}

Keywords: Characteristics of inflation, supply shock, demand shock, inflation, Indonesia.

JEL Classification: E31, P24

\footnotetext{
1 Merupakan inti sari dari materi yang disampaikan pada diskusi panel tentang "Indonesian Economic Outlook 2007", Program Pascasarjana FEUI - Bank Indonesia - Lippo Bank, Jakarta, 6 Januari 2007.

2 Penulis adalah peneliti ekonomi di Bank Indonesia dan pengajar tamu pada beberapa universitas. Kajian ini merupakan pandangan pribadi penulis dan tidak mencerminkan pandangan resmi Bank Indonesia. Email: solikin@bi.go.id .
} 


\section{PENDAHULUAN}

Dewasa ini, sejalan dengan kompleksitas mata rantai hubungan antara inflasi dengan beberapa variabel makro lainnya, sangatlah sulit untuk mengamati perilaku pembentukan harga secara spesifik. Sulitnya pengamatan terhadap perilaku variabel tersebut juga berkaitan dengan sulitnya mengidentifikasi/memprediksi sumber-sumber gejolak struktural (shocks) yang memicu tekanan inflasi, apakah dari sisi penawaran ataukah dari sisi permintaan, terutama apabila dikaitkan dengan rentannya perilaku kelembagaan yang berkaitan dengan kebijakan harga administered dan upah minimum oleh Pemerintah, serta perubahan peran keterbukaan ekonomi, yang dalam era global ini telah mempengaruhi bekerjanya mekanisme transmisi kebijakan moneter dalam beberapa tahun terakhir. Pengidentifikasian sumber-sumber shocks tersebut sangatlah penting. Dengan dapat diidentifikasikannya sumber-sumber shocks yang memicu tekanan inflasi dengan baik, maka positioning dari kebijakan moneter dapat ditentukan sehingga perumusan respons kebijakan dapat dilakukan dengan lebih terukur dan diimplementasikan secara lebih efektif.

Studi awal ini akan mengkaji karakteristik inflasi serta mengidentifikasi sumber-sumber shocks yang memicu tekanan inflasi di Indonesia. Selain untuk mencari kejelasan mengenai peran dominan suatu jenis shocks terhadap jenis shocks yang lain, analisis akan diarahkan juga untuk menginterpretasi seberapa kuat tekanan inflasi ke depan (inflation outlook). Berkaitan dengan itu, metode yang diajukan adalah adalah Structural Vector Autoregression (SVAR). Restriksi persamaan struktural jangka panjang merupakan pengembangan lebih lanjut dari pengidentifikasian yang dilakukan oleh Keating (2002), yaitu dengan memperhitungkan pengaruh penting dari keterbukaan ekonomi. Berdasarkan hasil penaksiran model, dapat disimpulkan bahwa dominasi kontribusi pengaruh total shocks sisi penawaran dibandingkan dengan shocks sisi permintaan pada perubahan harga selama lebih dari dua dekade terakhir adalah cukup 'proporsional', yaitu mencapai rata-rata 60\% - 40\%. Dalam kaitan ini, pengaruh shocks eksternal (nilai tukar) cenderung mengalami peningkatan, mensubstitusi pengaruh shocks penawaran agregat domsetik. Sementara itu, komposisi pengaruh shocks sisi permintaan didominasi oleh shocks moneter (pasar uang) serta cenderung mengalami perubahan yang tidak terlalu signifikan dari waktu ke waktu. Implikasi penting dari temuan tersebut adalah bahwa kebijakan moneter secara berhati-hati masih pada dasarnya dapat digunakan secara efektif untuk mempengaruhi inflasi (monetary policy is on its playing field).

Uraian paper ini akan dibagi menjadi lima bagian. Melanjutkan bagian pengantar di atas, bagian kedua akan mengulas karakteristik tekanan inflasi berdasarkan beberapa hasil studi terkini yang telah dilakukan sebelumnya. Bagian selanjutnya akan mengidentifikasi pengaruh dinamis gangguan sisi permintaan-penawaran melalui pengembangan model struktural. 
Sebelum bagian penutup yang akan mengetengahkan beberapa implikasi kebijakan, bagian ke empat akan menyampaikan analisis simulasi mengenai prospek tekanan inflasi dua tahun ke depan.

\section{KARAKTERISTIK INFLASI: BEBERAPA HASIL STUDI DAN IMPLIKASINYA}

Beberapa studi mengenai perilaku pembentukan harga atau inflasi telah banyak dilakukan di beberapa negara, yang umumnya dengan menggunakan pendekatan ekonometrik/makro dan data agregat (lihat Blanchard and Quah (1989); Gali (1992), Keating (1992), Jordan and Lenz (1994 and 1999), dan Gerlach and Smith (1995)). Sementara itu, studi serupa jarang/belum dilakukan untuk kasus Indonesia. Dua studi terkini mengenai perilaku pembentukan harga oleh Bank Indonesia mengetengahkan pendekatan survei (Bank Indonesia-DKM (2001), dan Bank Indonesia-PPSK (2003)). ${ }^{3}$ Keterbatasan studi pertama lebih disebabkan oleh cakupan survei yang lebih diarahkan pada pelaku kegiatan usaha di sektor industri manufaktur dan retail yang lebih merepresentasikan perilaku sisi penawaran. Selain itu, penelitian tersebut belum menyinggung secara nyata salah satu isu penting, yaitu masalah kekauan (rigidity). Studi berikutnya memperlengkapi hasil penelitian yang telah dilakukan sebelumnya, yaitu dengan mengakomodir beberapa aspek antara lain perilaku pembentukan upah di pasar input, perilaku kegiatan di sektor wholesale, serta penekanan analisis pada kekakuan harga (price rigidity). Secara umum, kedua studi tersebut menyimpulkan bahwa inflasi di Indonesia lebih disebabkan oleh dorongan biaya (cost-push), yang umumnya dipicu oleh kenaikan administered price, pajak, upah minimum, dan depresiasi rupiah. Sementara itu, tekanan sisi permintaan tidak begitu kuat, kecuali pada perayaan hari besar keagamaan. Temuan penting lainnya adalah pembuktian mengenai perilaku kekakuan harga yang bersifat downward rigidity.

Dari sisi Bank Indonesia, kuatnya pengaruh tekanan dari sisi penawaran tersebut mengimplikasikan pentingnya penerapan kebijakan moneter yang memberikan efek minimum pada struktur biaya perusahaan. Dalam hal ini, pengaruh kebijakan moneter terhadap struktur biaya dapat dibagi menjadi tiga saluran; yaitu expected inflation, nilai tukar, dan suku bunga. Kebijakan yang bersifat ekspansioner dapat menyebabkan terjadinya deprisiasi yang pada gilirannya dapat menaikan harga-harga produk manufacturing melalui peningkatan harga bahan baku yang diimpor. Kebijakan tersebut juga dapat meningkatkan ekspektasi inflasi baik secara langsung melalui sisi permintaan agregat maupun secara tidak langsung melalui

3 Lihat "Survey on Business Price Setting Behaviour", Kertas Kerja Penelitian, Bagian SSR-DKM, 2001 dan "Dinamika Pembentukan Harga dan Upah di Indonesia: Suatu Pendekatan Survei", Kertas Kerja Penelitian, PPSK, 2003. 
peningkatan harga barang-barang tradable. Di lain pihak ongkos perusahaan bisa jadi turun melalui penurunan pembayaran bunga atas kredit perbankan. Oleh karena itu efek bersih suatu kebijakan moneter terhadap struktur ongkos perusahaan sangat tergantung pada besaran efek nilai tukar dan ekspektasi inflasi yang berbanding terbalik dengan efek dari suku bunga. Selain itu, dengan karakteristik downward rigidity, Bank Indonesia perlu berhatihati dalam mengimplementasikan kebijakan yang bersifat kontraktif (Solikin dan Sugema, 2004).

Studi lain yang terkait dilakukan dengan menganalisis fenomena Kurva Phillips pada lingkup kegiatan ekonomi makro melalui pendekatan ekonometrik struktural (Solikin, 2004). Secara khusus, hal penting yang diamati adalah kemungkinan perubahan perilaku Kurva Phillips sebagai respons terhadap perubahan fundamental perekonomian, khususnya sebagai akibat krisis ekonomi 1997. Dari kajian tersebut disimpulkan bahwa fenomena Kurva Phillips eksis dalam perekonomian Indonesia, dimana keberadaan dan perilaku kurva tersebut mengalami perubahan dari waktu ke waktu, sejalan dengan perubahan struktur fundamental perekonomian (regime dependent). Secara khusus, pola pembentukan ekspektasi dan linieritas dalam Kurva Phillips mengalami perubahan yang signifikan antara periode pre dan pasca krisis. Dalam hal ini, pada periode pasca krisis slope Kurva Phillips cenderung lebih tajam (dan non-linier) dengan peranan pembentukan ekspektasi masyarakat yang cenderung forward looking. Slope yang lebih tajam menunjukkan bahwa tingkat kekakuan harga cenderung mengalami penurunan pada periode pasca krisis.

Paling tidak terdapat tiga implikasi mendasar dari temuan tersebut. Pertama, perubahan slope yang lebih tajam, di satu sisi menunjukkan semakin besarnya pengaruh permintaan domestik, sementara di sisi lain, respons sisi penawaran belum sepenuhnya mengimbangi perubahan sisi permintaan (lack of supply response). Kedua, berkaitan dengan fakta peningkatan peran ekspektasi tersebut, maka efektivitas pencapaian sasaran akhir kebijakan moneter dengan sasaran tunggal stabilitas harga akan sangat bergantung pada sejauhmana komitmen (kredibilitas) Bank Indonesia dalam mengupayakan perkembangan inflasi yang rendah dan stabil dalam kurun waktu tertentu secara konsisten, sejalan dengan masih cukup besarnya potensi permasalahan "persistent inflationary bias". Ketiga, kecendurungan non-linieritas (asimetri) Kurva Phillips, sejalan dengan hipotesis mengenai adanya 'capacity constraint' terutama pada periode krisis, mengimplikasikan perlunya perumusan kebijakan yang memperhitungkan stage dimana kondisi perekonomian sedang berada, sehingga perlu pula penetapan prioritas pertumbuhan ekonomi atau penurunan inflasi.

Temuan kedua dari studi mengenai Kurva Phillips diatas juga didukung oleh pengamatan mengenai persistensi tekanan inflasi yang dilakukan melalui analisis semiparametrik spektrum 
"Karakteristik Tekanan Inflasi di Indonesia:

atau spectral analysis (Solikin, 2005). Pendekatan yang digunakan tersebut ditujukan untuk mengukur sampai sejauhmana persistensi pengaruh shocks yang terjadi (random deviation from trend) terhadap perkembangan suatu variabel. Untuk variabel tidak stasioner (non-stationary), maka spectral density-nya akan lebih didominasi oleh nilai spectrum pada frekuensi rendah, sehingga pengaruh suatu shocks yang terjadi umumnya bersifat langgeng, dan sebaliknya. Dari hasil pengukuran, kepadatan spectrum dari inflasi, bersama dengan indikator sasaran akhir kebijakan yang lain, yaitu output gap dan perkembangangan kesempatan kerja mendominasi nilai spectrum pada frekuensi rendah. Hal tersebut berimplikasi bahwa variabel-variabel tersebut mempunyai tingkat persistensi terhadap shocks yang tinggi.

\section{IDENTIFIKASI PENGARUH DINAMIS GANGGUAN SISI PERMINTAAN- PENAWARAN}

Di luar beberapa temuan dan implikasi penting yang dihasilkan, ketiga studi yang dilakukan sebelumnya belum secara tegas mengidentifikasi seberapa besar dominasi sumber perubahan harga yang berasal dari sisi penawaran, serta perubahan pengaruh dari waktu ke waktu. Analisis berikut ini dimaksudkan untuk mengamati karakteristik tekanan inflasi di Indonesia, khususnya mengidentifikasi pengaruh dinamis gangguan sisi permintaan-penawaran. Dengan dasar pengidentifikasian tersebut, prospek tekanan inflasi ke depan akan diprakirakan lebih lanjut. Metode yang digunakan adalah Structural Vector Autoregression (SVAR) dengan rentang observasi triwulanan mulai 1980 sampai dengan 2006. Dengan melibatkan variabel-variabel harga, nilai tukar, output, suku bunga, dan besaran moneter, restriksi jangka panjang pada persamaan struktural dilakukan dengan mengacu pada Keating (2002). Untuk konteks perekonomian Indonesia yang small-open economy, modifikasi dilakukan dengan memperhitungkan pengaruh keterbukaan ekonomi, terutamanya dicerminkan oleh pengaruh gejolak nilai tukar (yang tidak diperhitungkan oleh Keating) pada veriabel-variabel ekonomi domestik. Dengan demikian, sistem persamaan struktural dan restriksi pengaruh antar variabel dapat diturunkan sebagai berikut.

Persamaan dasar dari struktur permodelan adalah log-linier dari versi model IS-LM, yang menetapkan kondisi keseimbangan di pasar barang dan pasar uang:

$$
\begin{aligned}
& i_{t}-E \Delta p_{t+1}=f+\beta_{1} y_{t} \\
& m_{t}-p_{t}=d+\beta_{2} y_{t}+\beta_{3} i_{t}
\end{aligned}
$$

dimana $i$ adalah suku bunga nominal, $p$ adalah harga domestik, $f$ adalah autonomous government expenditures, $y$ adalah pendapatan/output, $m$ adalah uang beredar, dan $d$ adalah autonomous part of money demand. Dengan asumsi bahwa variabel dalam persamaan (IV.1) 
dan (IV.2) terintegrasi dengan derajat I(1), maka diferensiasi pertama dari kedua persamaan tersebut adalah: ${ }^{4}$

$$
\begin{aligned}
& \Delta\left(i_{t}-E \Delta p_{t+1}\right)=\Delta \gamma_{1} y \\
& \Delta\left(m_{t}-p_{t}\right)=\gamma_{2} \gamma_{t}+\gamma_{3} i_{t}+u
\end{aligned}
$$

Sementara itu, kurva penawaran jangka panjang adalah vertikal, yang berarti bahwa dalam jangka panjang perubahan output dipengaruhi oleh shocks penawaran agregat $\left(u^{A S}\right)$ yang umumnya berasal dari sektor domestik. Perubahan penawaran uang beredar diasumsikan dipengaruhi oleh pendapatan/output, suku bunga, dan shocks di pasar uang $\left(u^{M D}\right.$ dan $\left.u^{M S}\right)$.

$$
\begin{aligned}
& \Delta y_{t}=u^{A S} \\
& \Delta m_{t}=\gamma_{4} \Delta y_{t}+\gamma_{5} \Delta i_{t}+\gamma_{6} \Delta u^{M D}+u^{M S}
\end{aligned}
$$

Dengan asumsi adanya cointegrasi antara $m$ dan $p$, maka persamaan (IV.4) dapat dirumuskan sebagai;

$$
\Delta p_{t}=\gamma_{4} \Delta y_{t}+\gamma_{5} \Delta i_{t}+\gamma_{6} \Delta u^{M D}+u^{M S}
$$

Pengembangan sistem persamaan dilakukan dengan memasukkan persamaan terakhir yang mengacu pada Purchasing Power Parity (PPP), yang diasumsikan bahwa dalam jangka panjang harga-harga sekumpulan barang dalam comon currency di negara yang berlainan ( $p$ dan $p^{*}$ ) akan meningkat secara one-for-one, sehingga yang tersisa adalah autonomous componen dari pengaruh sektor eksternal terhadap perekonomian domestik (a), dimana $\xi$ adalah disturbances dengan rata-rata nol. Dengan pemahaman bahwa nilai tukar (e) juga terintegrasi dengan derajat I(1), maka dalam jangka panjang depresiasi mata uang domestik akan dipengaruhi shocks eksternal yang bersifat autonomous.

$$
\begin{aligned}
& \left(p_{t}-p^{*}{ }_{t}\right)-e_{t}=a+\xi_{t} \\
& \Delta e_{t}=u^{E X}
\end{aligned}
$$

4 Pengujian stasioneritas dilakukan secara intensif pada studi sebelumnya (lihat Solikin, 2005), dengan menggunakan beberapa metode, antara lain Augmented Dickey-Fuller (ADF) test, Phillips-Perron (PP) test, Elliot-Rothenber-Stock (ERS) test dan Ng-Perron (NP) test. Hasil pegujian dengan menggunakan ADF test pada tingkat signifikasi $95 \%$ dan batas pengujian pada lag sama dengan 4 , dapat diperlihatkan bawa dalam bentuk level, pengujian pada umumnya tidak dapat menolak hipotesis nol tentang adanya unit-root pada semua variabel (kecuali suku bunga SBI dan LIBOR), yang berarti bahwa semua variabel (kecuali suku bunga) bersifat non-stasioner pada tingkat signifikasi $95 \%$. Sementara itu, dalam bentuk first difference, hasil pengujian menolak hipotesis nol tentang adanya unit-root pada semua variabel semua variabel bersifat stasioner. Suku bunga mempunyai signifikasi derajat penolakan terhadap nilai kritis yang lebih besar. Dari hasil tersebut dapat disimpulkan bahwa semua variabel dalam sistem memiliki derajat integrasi 1, atau I(1). Dalam hal ini, suku bunga cenderung bersifat "close to (non) stasionary".

Hasil pengujian dengan menggunakan metode lainnya memberikan kesimpulan yang secara umum sama dengan hasil pengujian ADF test, yaitu bahwa variable-variabel makro yang ada dalam sistem permodelan mempunyai karakteristik I(1), yaitu non-stasioner pada bentuk level, tapi stasioner pada bentuk first-difference. 
Dengan beberapa restriksi tersebut, maka sistem persamaan dapat diformulasikan dalam hubungan antara variabel endogen dengan shocks struktural sebagai berikut.

$$
\left[\begin{array}{c}
\Delta e \\
\Delta y \\
\Delta(i-p) \\
\Delta(m-p) \\
\Delta p
\end{array}\right]=\left[\begin{array}{cccccc}
1 & 0 & 0 & 0 & 0 & u^{E X} \\
0 & 1 & 0 & 0 & 0 & u^{A S} \\
a^{1} & a^{2} & 1 & 0 & 0 & u^{I S} \\
a^{3} & a^{4} & a^{5} & 1 & 0 & u^{M D} \\
a^{6} & a^{7} & a^{8} & a^{9} & 1 & u^{M S}
\end{array}\right]
$$

Dari persamaan struktural tersebut paling tidak dapat dilihat dua hal, yaitu pola restriksi netralitas jangka panjang (long-run neutrality restrictions) dan aggregasi dari sumber shocks. Dalam hal ini, restriksi struktural menyatakan bahwa hanya penawaran agregat yang umumnya berasal dari sektor domestik yang mempunyai pengaruh permanen pada output, shocks moneter (pasar uang) tidak mempunyai pengaruh permanen pada suku bunga, serta shocks penawaran uang tidak mempunyai pengaruh permanen pada real money balances. Sementara itu, berkaitan dengan agregasi sumber shocks, formulasi persamaan tersebut dapat disederhanakan menjadi shocks sisi penawaran dengan dekomposisi $u^{E X}$ dan $u^{A S}$, serta shocks sisi permintaan dengan dekomposisi $u^{I S}, u^{M D}$ dan $u^{M S}$, sebagaimana Bayoumi and Eichengreen (1993) yang mengetengahkan model sederhana dengan dua variabel utama, yaitu output dan harga. Penyertaan $u^{E X}$ sebagai komponen dari shocks sisi penawaran dikarenakan pengaruh pass through dari gejolak sektor eksternal dan nilai tukar yang pada umumnya melalui perubahan harga bahan baku (di pasar input) dan daya saing ekonomi secara keseluruhan.

Dengan memperhitungkan stasioneritas variabel-variabel di sisi kiri persamaan (IV.6), yaitu perubahan nilai tukar rupiah/USD, PDB riil, suku bunga SBI riil, uang primer riil, dan IHK —selain suku bunga SBI riil semua variabel dalam log--, penaksiran model SVAR dilakukan dengan lag autoregressive 2 periode dalam beberapa rentang observasi yang berbeda. ${ }^{5}$ Hasil penaksiran model pada dasarnya dapat dilihat pada analisis impulse response function dan dekomposisi varians (variance decomposition) dari forecast error sistem persamaan. Dalam hal ini, secara umum,

5 Dalam Solikin (2005), pemilihan panjang lag (order) dilakukan dengan menggunakan tolok ukur kriteria informasi (information criteria), yaitu Akaike Infotmation Criterion (AIC) dan Schwarz Bayesian Criterion (SBC), maupun Hannan-Quinn Criterion (HQC). Pada penelitian ini batas maksimal lag yang diperhitungkan adalah empat. Dari hasil pengujian berdasarkan SBC, order yang dipilih adalah satu, sementara berdasarkan AIC order yang dipilih adalah empat. Terdapat indikasi atau kemungkinan bahwa order berada di antara nilai "ekstrim" tersebut. Dengan demikian, aspek penting lain yang yang perlu dipertimbangkan adalah kondisi bahwa dengan rentang periode yang tidak terlalu lama, pemilihan order yang lebih pendek akan menghindari permasalahan "overparametrization". Selain itu, dari uji statistik uji kestasioneran menunjukkan bahwa order of augmented variabel umumnya berkisar antara satu sampai dengan tiga. Berdasarkan beberapa informasi tersebut, dapat dipertimbangkan bahwa order model VAR yang "optimal" adalah dua. 
konsistensi teoritis dari hubungan antar variabel dalam sistem dapat dilihat pada plot generalized impulse responseyang menunjukkan kesesuaian arah pengaruh dari variabel-variabel dalam sistem terhadap perubahan harga atau inflasi, terutama pada $2-4$ periode pertama. ${ }^{6}$ Secara spesifik, persistensi shocks internal pada inflasi berlangsung selama 4 periode (Lampiran IV.1).

Sementara itu, perubahan pengaruh dinamis dari sisi permintaan dan penawaran terhadap perubahan harga dari periode tertentu ke periode yang lain diamati berdasarkan rata-rata dekomposisi varians (variance decomposition) pada dua belas periode (horizon) ke depan, sebagai berikut.

\begin{tabular}{|c|c|c|c|c|c|c|}
\hline \multirow{3}{*}{ Periode Observasi } & \multicolumn{6}{|c|}{$\begin{array}{l}\text { Tabel IV.1 } \\
\text { perubahan harga dalam merespons } \\
\text { Iaran (rata-rata } 12 \text { periode ke depan) Periode }\end{array}$} \\
\hline & \multicolumn{3}{|c|}{ Shocks Sisi Penawaran (\%) } & \multicolumn{3}{|c|}{ Shocks Sisi Permintaan (\%) } \\
\hline & $u^{E X}$ & $u^{A S}$ & Total & $u^{I S}$ & $u^{M S}+u^{M D}$ & Total \\
\hline $1980.1-1995.4$ & 8 & 50 & 58 & 3 & 39 & 42 \\
\hline $1980.1-2000.4$ & 15 & 40 & 55 & 3 & 42 & 45 \\
\hline $1980.1-2005.4$ & 30 & 30 & 60 & 5 & 35 & 40 \\
\hline
\end{tabular}

Dari Tabel IV.1 paling tidak dapat disimpulkan mengenai tiga aspek penting sebagai berikut. Pertama, bahwa rata-rata kontribusi pengaruh total shocks sisi penawaran pada perubahan harga selama lebih dari dua dekade terakhir adalah 55-60\%, lebih besar dibandingkan dengan kontribusi pengaruh total shocks sisi permintaan yang berkisar $40-45 \%$. Kesimpulan ini sejalan dengan hasil studi-studi yang telah dilakukan sebelumnya mengenai relatif dominannya pengaruh sisi penawaran (non-moneter) pada perkembangan inflasi di Indonesia. Kedua, sejalan dengan kecenderungan peningkatan kontribusi peran shocks sisi penawaran, pengaruh shocks eksternal (nilai tukar) cenderung mengalami peningkatan, mensubstitusi pengaruh shocks penawaran agregat. Kesimpulan kedua sejalan dengan kecenderungan perubahan mekanisme transmisi yang terjadi di beberapa negara yang antara lain terkait dengan peningkatan peran perubahan nilai tukar dalam mempengaruhi pencapaian target kebijakan moneter (BIS, 2006). Ketiga, komposisi pengaruh shocks sisi permintaan didominasi oleh shocks moneter (pasar uang) serta cenderung mengalami perubahan yang tidak terlalu signifikan dari waktu ke waktu.

6 'Generalized' impulse response merupakan pendekatan yang tidak memerlukan pengortogonalisaian shocks (sebagaimana 'orthogonalized' impulse response) dan tidak terpengaruh oleh urutan variabel dalam sistem model VAR. Dalam kaitan ini, untuk untuk suatu matrik error variance yang non-diagonal, 'orthogonalized' dan 'generalized' impulse response memiliki kesamaan hanya pada kasus pengenaan impulse reseponse dari shocks pada persamaan pertama dalam sistem model VAR. 


\section{SIMULASI PROSPEK TEKANAN INFLASI 2007 - 2008}

Untuk tujuan yang bersifat analitis, simulasi prospek tekanan inflasi dilakukan dengan menggunakan analisis impulse response function. Landasan pemikiran akan langkah ini adalah bahwa penaksiran respons total dari perubahan harga terhadap satu simpangan baku 'inovasi' dari semua variabel dalam sistem dapat dipakai sebagai rujukan mengenai seberapa kuat pengaruh tekanan variabel-variabel tersebut terhadap perubahan harga ke depan. Dengan menggunakan hasil penaksiran impulse periode observasi 1980.1 - 2005.4 sebagai benchmark untuk menggambarkan tekanan pada perbuhan harga pada saat ini (current state), maka dapat dilihat apakah hasil penaksiran impulse (ke depan) dari periode observasi yang diperluas setahun kemudian (1980.1 - 2006.4) secara relatif lebih kuat atau lemah. Hasil penaksiran rasio total response perubahan harga pada dua kondisi yang berbeda tersebut dapat disampaikan sebagai berikut.

\begin{tabular}{|c|c|c|c|c|}
\hline \multicolumn{5}{|c|}{$\begin{array}{l}\text { Tabel IV.2a } \\
\text { Total impulse response function dari perubahan harga } \\
\text { terhadap 'inovasi' pada semua variabel dalam sistem }\end{array}$} \\
\hline $\begin{array}{l}\text { Periode } 2 \text { tahun } \\
\text { ke depan (kuartal) }\end{array}$ & $\begin{array}{c}\text { Benchmark } \\
\text { (1) }\end{array}$ & $\begin{array}{c}1980-2006 \\
(2)\end{array}$ & $\begin{array}{l}\text { Rasio * } \\
(2) /(1)\end{array}$ & $\begin{array}{c}\text { Rata-rata Rasio } \\
\text { (1 tahun) }\end{array}$ \\
\hline 1 & 0.018 & 0.019 & 1.02 & \\
\hline 2 & 0.017 & 0.016 & 0.96 & \\
\hline 3 & 0.023 & 0.021 & 0.93 & \\
\hline 4 & 0.007 & 0.007 & 0.90 & 0.95 \\
\hline 5 & 0.001 & 0.001 & 0.85 & \\
\hline 6 & -0.005 & -0.005 & 1.00 & \\
\hline 7 & -0.003 & -0.003 & 1.07 & \\
\hline 8 & -0.003 & -0.003 & 0.94 & 0.96 \\
\hline
\end{tabular}

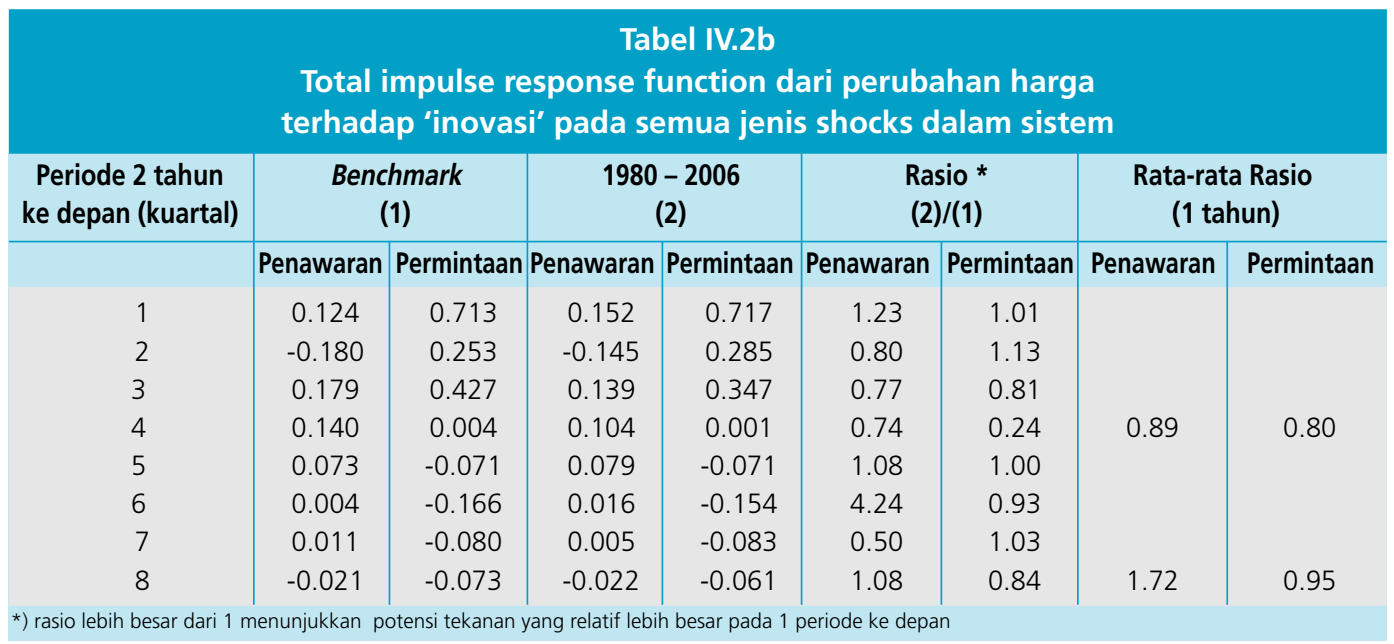


Dari Tabel IV.2a dapat dilihat bahwa secara umum, total pengaruh inovasi variabel-variabel dalam sistem terhadap perubahan harga relatif tidak berbeda jauh antara periode benchmark dan periode 1980 - 2006. Dalam hal ini, selama dua tahun ke depan rata-rata tekanan pada perubahan harga diperkirakan akan sedikit melemah, menjadi rata-rata 95 - 96\% dari rata tekanan pada periode benchmark. Tekanan yang cukup kuat akan terjadi pada kuartal pertama dan pertengahan tahun kedua. Namun, apabila dilihat komposisinya, pengaruh inovasi perubahan nilai tukar mempunyai kecenderungan melemah paling tidak pada lima kuartal pertama dan kemudian menguat, sementara pengaruh inovasi perubahan output mempunyai kecenderungan menguat mulai triwulan ketiga (Lampiran IV.2). Sementara itu, berdasarkan Tabel IV.2b, terlihat kecenderungan penguatan pengaruh shocks penawaran agregat yang signifikan terutama pada tahun kedua. Sementara itu, pengaruh shocks permintaan agregat, walaupun mengalami penguatan namun masih cenderung di bawah benchmark.

Dari hasil simulasi awal tersebut dapat disimpulkan bahwa tekanan inflasi dua tahun mendatang secara statistik akan cenderung relatif sama dengan tekanan inflasi tahun 2006. Secara numerik, dengan laju inflasi tahunan 2006 yang mencapai 6,6\%, inflasi tahun 2007 dan 2008 masing-masing diperkirakan akan mencapai angka sekitar 6,3\% dan 6\%. Untuk tahun 2007, angka perkiraan tersebut tidak jauh berbeda dengan angka perkiraan beberapa lembaga kajian ekonomi, seperti terlihat pada tabel berikut.

\begin{tabular}{|c|c|c|c|c|c|c|}
\hline \multicolumn{7}{|c|}{$\begin{array}{c}\text { Tabel IV.3 } \\
\text { Perkiraan Ekonomi Indonesia } 2007 \text { (\%) }\end{array}$} \\
\hline & Pemerintah & BI & IMF & ADB & IBII & Realisasi 2006 \\
\hline $\begin{array}{l}\text { Pertum.Ekonomi } \\
\text { Inflasi }\end{array}$ & $\begin{array}{l}6,3 \\
6,5\end{array}$ & $\begin{array}{c}5,7-6,3 \\
6+1\end{array}$ & $\begin{array}{l}6,0 \\
5,9\end{array}$ & $\begin{array}{l}6,0 \\
7,5\end{array}$ & $\begin{array}{l}6,0 \\
6,6\end{array}$ & $\begin{array}{l}5,5 \\
6,6\end{array}$ \\
\hline
\end{tabular}

Perlu dikemukakan bahwa, disamping temuan tersebut, terdapat beberapa risiko yang perlu diwaspadai. Pertama, walaupun secara statistik relatif sama, tekanan inflasi pada tahun 2008 berpotensi lebih tinggi dibandingkan tahun 2007, selaras dengan mulai menguatnya tekanan/pengaruh perubahan nilai tukar. Satu hal lain yang juga perlu diwaspadai adalah munculnya potensi risiko dari peningkatan tekanan inflasi yang lebih besar lagi, yaitu yang bersumber baik dari dorongan peningkatan kegiatan ekonomi pada paro pertama 2007, maupun gejolak di sisi penawaran, seperti harga barang administered dan kelompok volatile food, sejak awal tahun 2008. Sementara itu, dari sisi eksternal, ketidakpastian perkembangan harga minyak di pasar internasional berpotensi memberikan tekanan pada inflasi. Namun, sejalan dengan perlemahan tekanan sisi penawaran pada tahun 2007, pengaruh perubahan harga minyak dunia pada inflasi diperkirakan tidak begitu ekstrim dan cenderung netral. Potensi pengaruh perubahan harga minyak diperkirakan akan muncul pada tahun 2008. 
"Karakteristik Tekanan Inflasi di Indonesia:

\section{IMPLIKASI KEBIJAKAN}

Paling tidak terdapat empat implikasi kebijkan dari temuan studi awal ini, yaitu sebagai berikut. Pertama, walaupun secara total kontribusi pengaruh shocks sisi penawaran pada perubahan harga lebih besar dibandingkan dengan total kontribusi pengaruh shocks sisi permintaan, perbedaan yang terjadi relatif proporsional, yaitu rata-rata $55-60 \%$ dibanding 40 $45 \%$. Hal ini sangat berbeda dengan penafsiran beberapa hasil studi sebelumnya yang secara tersirat menunjukkan pengaruh yang sangat dominan shocks sisi penawaran, sehingga ada kecenderungan pemahaman bahwasanya dinamika inflasi adalah fenomena struktural/nonmoneter. Dengan demikian, temuan di atas mengimplikasikan bahwa kebijakan moneter secara berhati-hati, terutama melalui pengendalian likuiditas, masih dapat digunakan secara efektif untuk mempengaruhi inflasi (monetary policy is on its playing field). Hal ini dapat dilihat pada pengaruh inovasi pada suku bunga riil yang signifikan dalam pengendalian inflasi pada 2-3 periode ke depan. Bahkan, dilihat dari kontribusi pengaruh shocks eksternal (nilai tukar) yang cukup signifikan, kebijakan moneter dapat berperan melalui saluran nilai tukar (exchange rate channel). Paling tidak, hal ini dapat dilihat pada kurun waktu setahun terakhir, dimana keberhasilan Bank Indonesia dalam memelihara nilai tukar pada level yang diharapkan telah berhasil menurunkan passthrough effect dari gejolak nilai tukar pada inflasi.

Kedua, relatif besarnya kontribusi pengaruh shocks sisi penawaran pada perubahan harga juga mengimplikasikan bahwa pelaksanaan kebijakan moneter dengan penargetan inflasi berpotensi mengalami hambatan terutama karena (ekspektasi) inflasi lebih didominasi oleh variabel-variabel sisi penawaran yang berada di luar jangkauan otoritas moneter seperti administered price dan harga sembako. Artinya, untuk mengarahkan inflasi ke arah yang diinginkan, maka sangat diperlukan upaya sinkronisasi kebijakan antara otoritas moneter dan otoritas fiskal dan perdagangan.

Ketiga, walaupun tekanan inflasi ke depan diperkirakan relatif rendah (sama) dibandingkan dengan tekanan inflasi pada tahun 2006, serta ruang pelonggaran moneter cukup terbuka, kebijakan moneter tetap perlu dilakukan secara berhati-hati (cautious); agar tidak memberikan dampak yang berlebihan pada perlemahan nilai tukar ke depan (lag 1,5 tahun), thus peningkatan tekanan inflasi.

Last but not least, dengan memperhitungkan perkiraan akan meningkatnya potensi tekanan inflasi ke depan yang cukup persisten, terutama yang bersumber dari gejolak di sisi penawaran di satu sisi, serta adanya kecenderungan lemah/lambatnya respons sisi penawaran (lack of supply response) terhadap peningkatan permintaan agregat di sisi lain, maka sejalan dengan penerapan kebijakan moneter yang kredibel, kebijakan ekonomi makro ke depan perlu diarahkan pada pembenahan sisi penawaran, khususnya sektor produksi yang mendukung kelancaran pasokan barang dan peningkatan penggunaan kapasitas produksi, serta kebijakan reformasi struktural yang mendukung peningkatan investasi dan efisiensi usaha. 


\section{REFERENSI}

Bank Indonesia (2001), "Survey on Business Price Setting Behaviour", Kertas Kerja Penelitian, Bagian SSR-DKM.

Bank Indonesia (2003), "Dinamika Pembentukan Harga dan Upah di Indonesia: Suatu Pendekatan Survei", Kertas Kerja Penelitian, PPSK.

Blanchard, Olivier J. and Danny Quah (1989), "The Dynamic Effects of Aggregate Demand and Supply Disturbances", The American Economic Review, Vol 74/No.4.

Bayoumi and Eichengreen (1993), "Shocking Aspects of European Monetary Unification", in F.Torres and F.Giavazzi (eds.), Adjustment and Growth in the European Monetary Union, Cambridge University Press, Cambridge (UK).

Bank for International Settements (2006), "Transmission Mechanism for Monetary Policy in Emerging Market Economies: What is New?", BIS Briefing Paper.

Gali,J.(1992), "How Well does The IS-LM Model at Post War U.S.Data?", The Quarterly Journal of Economics, 107:709 -738.

Gerlach,S.and F.Smets (1995), "The Monetary Transmission Mechanism:Evidence from The G-

7 Countries", Discussion Paper 1219, Center for European Policy Research.

IBII (2006), Makroekonomi Indonesia 2006-2007, LPE-IBII.

Jordan, T.J and C. Lenz (1994), "Demand and Supply Shocks in the IS-LM Model: Empirical Findings for Five Countries", Working Paper 94-8, Universitat Bern. (1999), "Identifcation of Macroeconomic Shocks: Variations on the IS-LM Model", Swiss National Bank Working Paper.

Keating, J.W.(1992), "Structural Approaches to Vector Autoregressions", Federal Reserve Bank f St.Louis Review, 74(5):37 -57.

Solikin (2005), "Analisis Kebijakan Moneter dalam Model Makroekonometrik Jangka Panjang: Structural Cointegrating Vector Autoregression", Buletin Ekonomi Moneter dan Perbankan (BEMP), September, Bank Indonesia. 
(2004), "Kurva Phillips dan Perubahan Struktural di Indonesia: Keberadaan, Linearitas, dan Pembentukan Ekspektasi", Buletin Ekonomi Moneter dan Perbankan (BEMP), Maret, Bank Indonesia.

dan Imam Sugema (2004), "Rigiditas Harga-Upah dan Implikasinya bagi Kebijakan Moneter di Indonesia", Buletin Ekonomi Moneter dan Perbankan (BEMP), September, Bank Indonesia. 


\section{Lampiran IV.1. Respons Inflasi terhadap Inovasi pada Sistem}
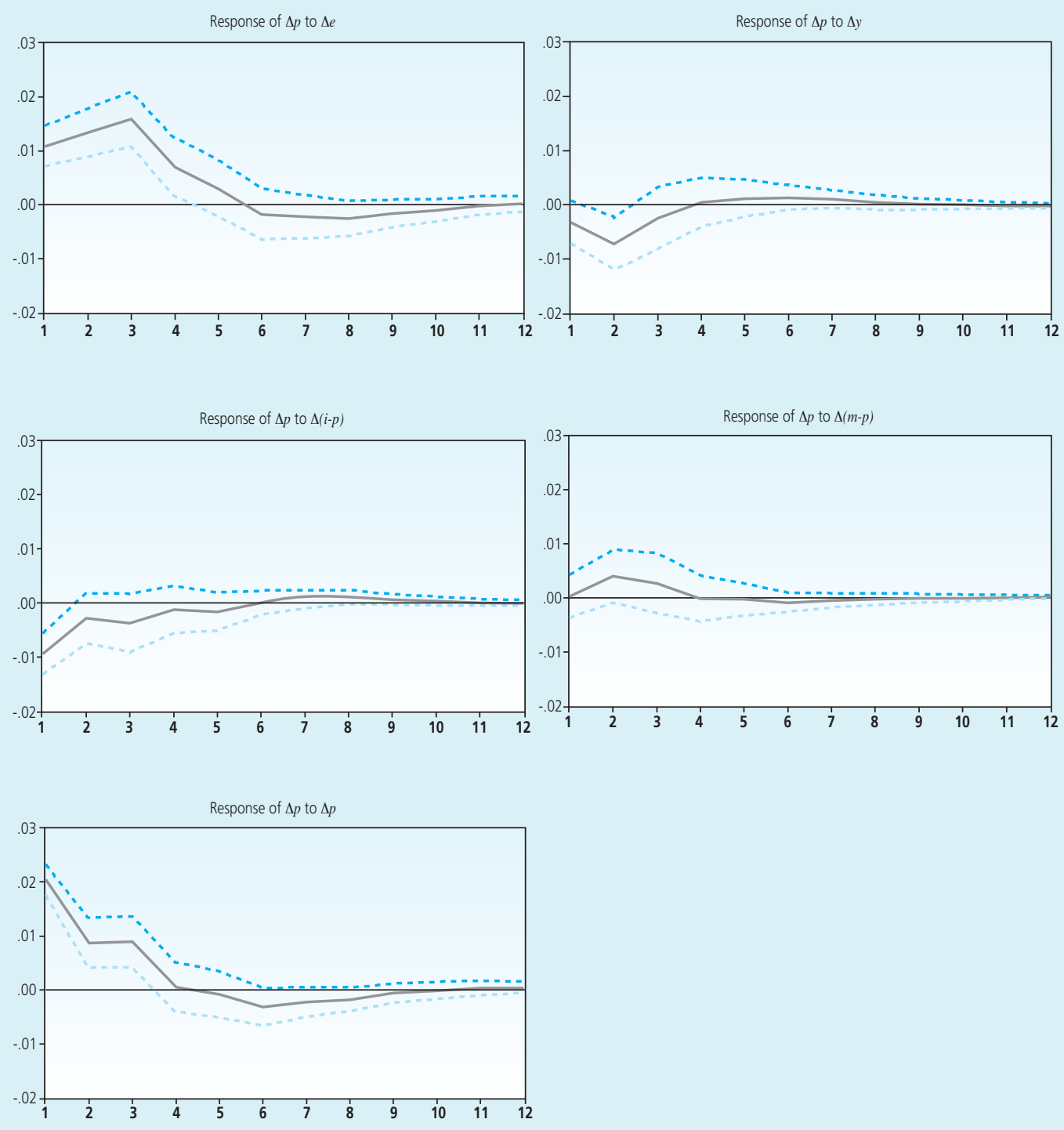

\section{Grafik IV.1}

Response to generalized One S.D. Innvations \pm 2 S.E. 
Response of $\Delta p$ to $U^{E X}$

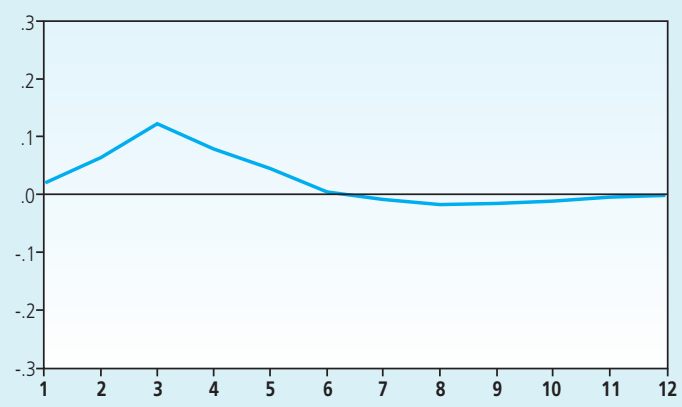

Response of $\Delta p$ to $U^{t s}$

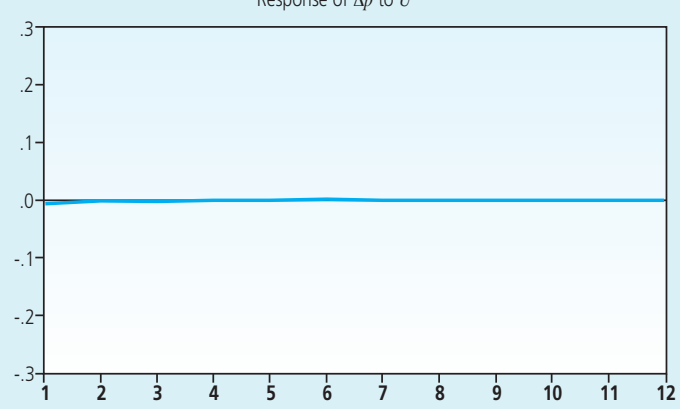

Response of $\Delta p$ to $U^{\text {MS }}$

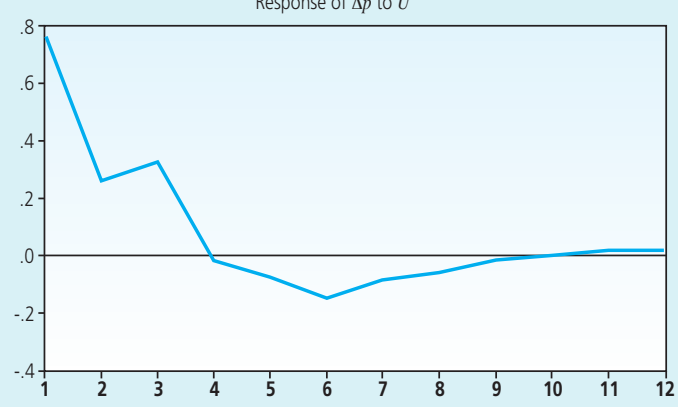

Response of $\Delta p$ to $U^{A s}$

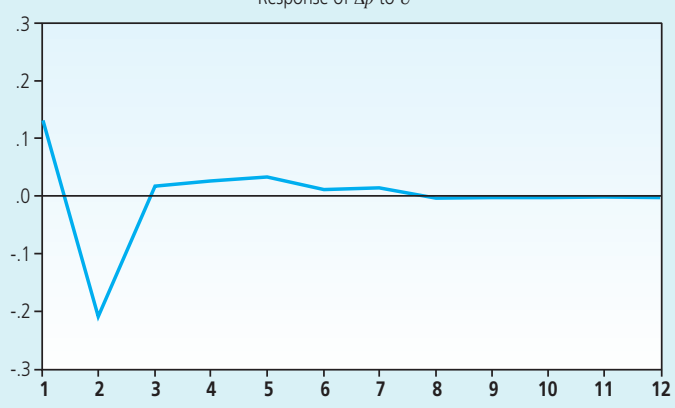

Response of $\Delta p$ to $U^{M i}$

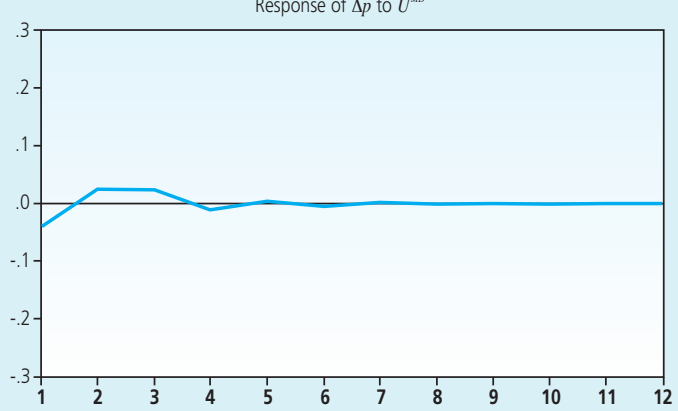

Grafik IV.1

Response to generalized One S.D. Innvations +2 S.E. (Lanjutan) 


\section{Lampiran IV.2.}

\section{Tabel Lampiran IV.2.1}

Rasio Impulse response function dari perubahan harga $(\Delta p)$ terhadap 'inovasi' pada semua variabel dalam sistem*

\begin{tabular}{c|c|c|c|c|c} 
Period & $\Delta \mathbf{e}$ & $\Delta \mathbf{y}$ & $\Delta(\mathbf{i}-\mathbf{p})$ & $\Delta(\mathbf{m}-\mathbf{p})$ & $\Delta \mathbf{p}$ \\
1 & 0.98 & 0.90 & 0.94 & 0.94 & 0.98 \\
2 & 0.97 & 1.01 & 1.04 & 1.04 & 0.97 \\
3 & 0.98 & 1.17 & 0.92 & 0.87 & 0.91 \\
4 & 0.97 & 0.55 & 1.04 & -1.83 & 1.18 \\
5 & 0.90 & 1.19 & 0.95 & 1.19 & 1.14 \\
6 & 1.13 & 1.19 & -0.46 & 0.99 & 0.99 \\
7 & 1.07 & 1.00 & 0.87 & 1.14 & 0.97 \\
8 & 0.96 & 0.86 & 0.88 & 0.87 & 0.86
\end{tabular}

